\title{
Natural History Notes of Saurophagy: An Update from the Puerto Rican Vertebrate Fauna ${ }^{5}$
}

\author{
Neftalí Ríos-López ${ }^{6}$, Rafael L. Joglar ${ }^{7}$, Carlos A. Rodríguez-Gómez ${ }^{8}$, \\ Carlos J. Díaz-Vázquez ${ }^{9}$, and Israel Rivera ${ }^{10}$
}

\begin{abstract}
We document the first accounts of lizard predation from Puerto Rico by native and naturalized species of lizards, snakes, birds, and mammals (domestic and feral). Specifically, we document saurophagy by the lizards Anolis cristatellus and Ameiva exsul; the colubrid Borikenophis portoricensis; several species of non-raptor birds; and feral and domestic mammals. Lizard prey includes Anolis cristatellus, A. pulchellus, A. stratulus, Ameiva exsul, Iguana iguana (including eggs and embryos), and Sphaerodactylus monensis. These accounts add to our knowledge on trophic relationships and predator-prey interactions in Puerto Rico, with emphasis on the role of naturalized species on local food webs.
\end{abstract}

Key Words: Ameiva exsul, Anolis, avian predation, Borikenophis portoricensis, domestic mammals, Iguana iguana, saurophagy, seabirds, Small Indian Mongoose.

The herpetofauna is an important component for many ecosystem processes, especially in tropical islands. On Caribbean islands, for example, the large mammals and predatory species that characterize continents are lacking, making amphibians and reptiles, along with birds, the most abundant and conspicuous predators (Odum et al. 1970; García-Moll 1978; Reagan 1996a; Reagan et al. 1996; Duellman 1999). In a Puerto Rican tropical rain forest, for example, the combined population density of three species of Anolis (Squamata: Dactyloidae) and the Common Coquí (Anura: Eleutherodactylidae: Eleutherodactylus coqui Thomas, 1966) reached 49,800 individuals ha $^{-1}$ (Reagan 1996b; Stewart and Woolbright 1996). One of these species, the Puerto Rican Saddle Anole (A. stratulus Cope, 1861), has the second highest density documented for any lizard elsewhere with $>2$ individuals $/ \mathrm{m}^{2}$ (Reagan 1992; Reagan et al. 1996) (the highest being from the Common Dwarf Gecko or 'Salamanquita de la Virgen' [Squamata: Gekkonidae: Sphaerodactylus

\footnotetext{
${ }^{5}$ Submitted on May 26, 2015. Accepted on June 26, 2015. Final revisions received on July 22, 2015.

${ }^{6}$ Department of Biology, University of Puerto Rico-Humacao, Call Box 860, Humacao, Puerto Rico 00792 USA. E-mail: neftali.rios@upr.edu, neftalirios@yahoo.edu

${ }^{7}$ Department of Biology, University of Puerto Rico-Río Piedras, PO Box 23360, San Juan, Puerto Rico 00931-3360 USA. E-mail: rjoglar@gmail.com

${ }^{8}$ HC 5 Box 9608 Río Grande, Puerto Rico 00745 USA. E-mail: ca.rodriguezgomez@ gmail.com

${ }^{9}$ HC 1 Box 29030 PMB 147, Caguas, Puerto Rico 00725 USA. E-mail: skydraw00@me.com

${ }^{10}$ PO Box 2659, Juncos, Puerto Rico 00777 USA. E-mail: israelrivera729@ gmail.com
} 
macrolepis Günther, 1859] with $>5$ individuals $/ \mathrm{m}^{2}$; Rodda et al. 2001). As this species assemblage alone can consume $>550,000$ prey items $\mathrm{ha}^{-1} \mathrm{~d}^{-1}$, mainly insects (Reagan 1996b), they can regulate community structure and ecosystem processes through predator-prey interactions. Consequently, the high abundance and predation activity makes the Caribbean herpetofauna a major component in the local ecosystem energy, carbon, and nutrient flows (García-Moll 1978; Roughgarden 1995; Reagan 1996b; Reagan et al. 1996; Rodda et al. 2001; Beard et al. 2003; Hillman et al. 2009).

Species of the Puerto Rican herpetofauna are preyed by higher-level vertebrate consumers, with cannibalism and oophagy (including filial) being more common than frequently acknowledge (Reagan 1996b; Reagan et al. 1996; Stewart and Woolbright 1996; Acevedo-Torres et al. 2005; Henderson and Powell 2009; Powell and Watkins 2014). For reasons stated above, documenting predation events is important to better understand the contribution of each taxonomic or functional guild of herpetofaunal predators and preys, as regulators of ecosystem processes and species assemblages on islands. Consequently, our main objective is to document predation events in which a lizard, as prey, is engaged in an inter-specific predator-prey interaction in Puerto Rico.

\section{Interspecific Predation of Lizards}

Lizard-Lizard saurophagy. On June 4, 2014, J. Santiago-Blay found a male Puerto Rican Crested Anole (Anolis cristatellus Duméril and Bibron, 1837) ingesting, head first, an adult Puerto Rican Grass Anole (A. pulchellus Duméril and Bibron 1837) (Figure 1).

The anoles were approximately at $1.5 \mathrm{~m}$ aboveground on a tree trunk (unidentified species) at the edge of a pasture area. This observation took place at about $0830 \mathrm{~h}$ on the side of the road PR-412, 5 road km. east of the center of Rincón municipality, Puerto Rico (WGS 84, coordinates $18.325^{\circ} \mathrm{N}, 67.216^{\circ} \mathrm{W}$ ). Although not moving at the time of the observation, A. pulchellus has appeared recently dead and had fresh wounds on its broken tail suggesting that $A$. cristatellus may have hunted it. During the 10 minutes we stayed observing, the A. cristatellus moved circa $15 \mathrm{~cm}$ to its right in one rapid burst, remaining at approximately the same level aboveground while holding the A. pulchellus firmly in its mandibles. 


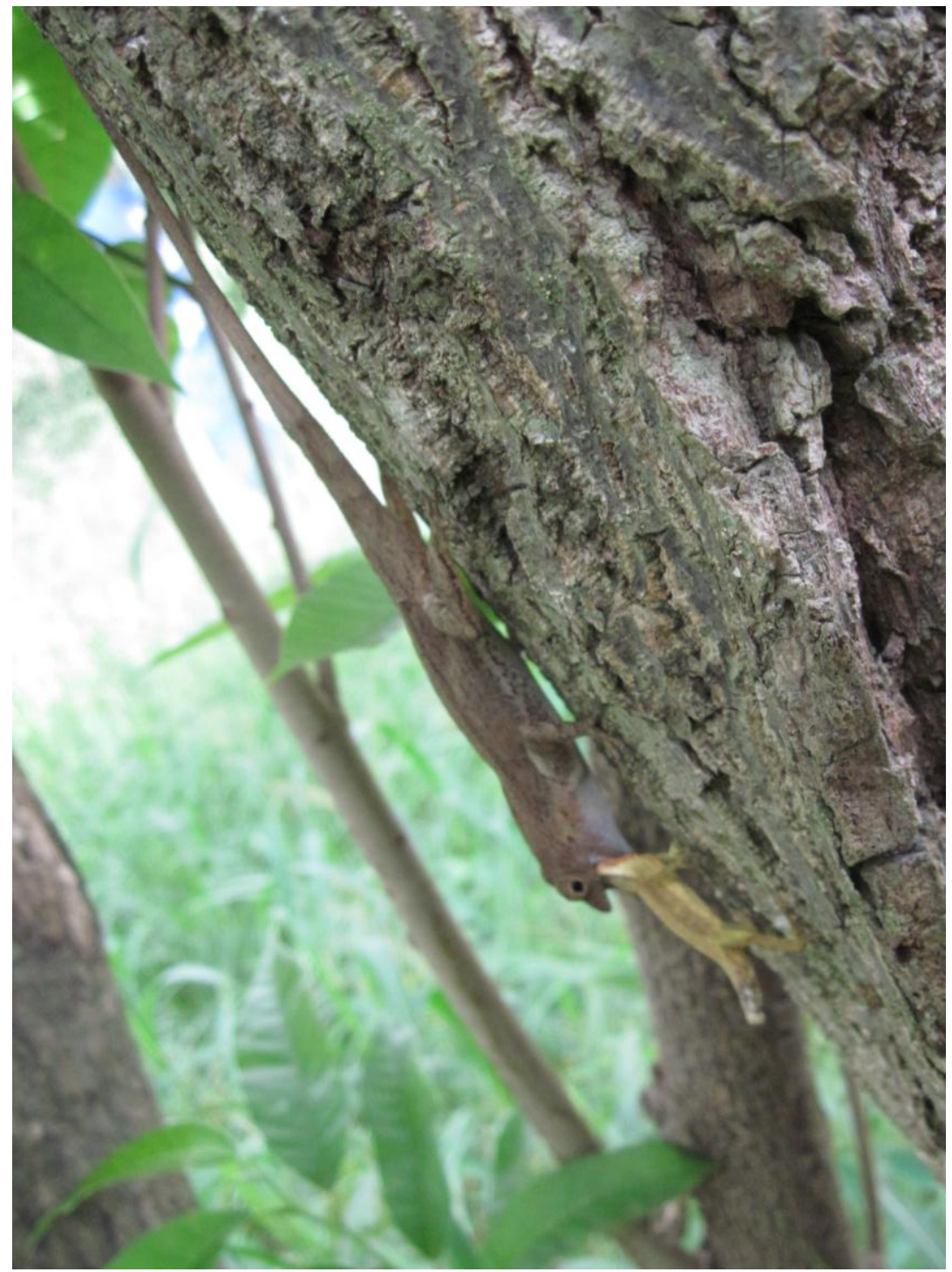

Figure 1. Male Anolis cristatellus ingesting an A. pulchellus. Photo by J. Santiago-Blay.

A three-species interaction involved Anolis cristatellus (killer), A. stratulus (prey), and the Puerto Rican 'Siguana' (common name in Spanish) or Puerto Rican Ground Lizard, Ameiva exsul Cope, 1862 (Squamata: Teiidae). On September 28, 2009, NRL observed a male A. cristatellus that captured by the 
head a male A. stratulus, which was displaying its dewlap at $1.8 \mathrm{~m}$ aboveground on a Eugenia sp. (unidentified tree) (Figure 2).

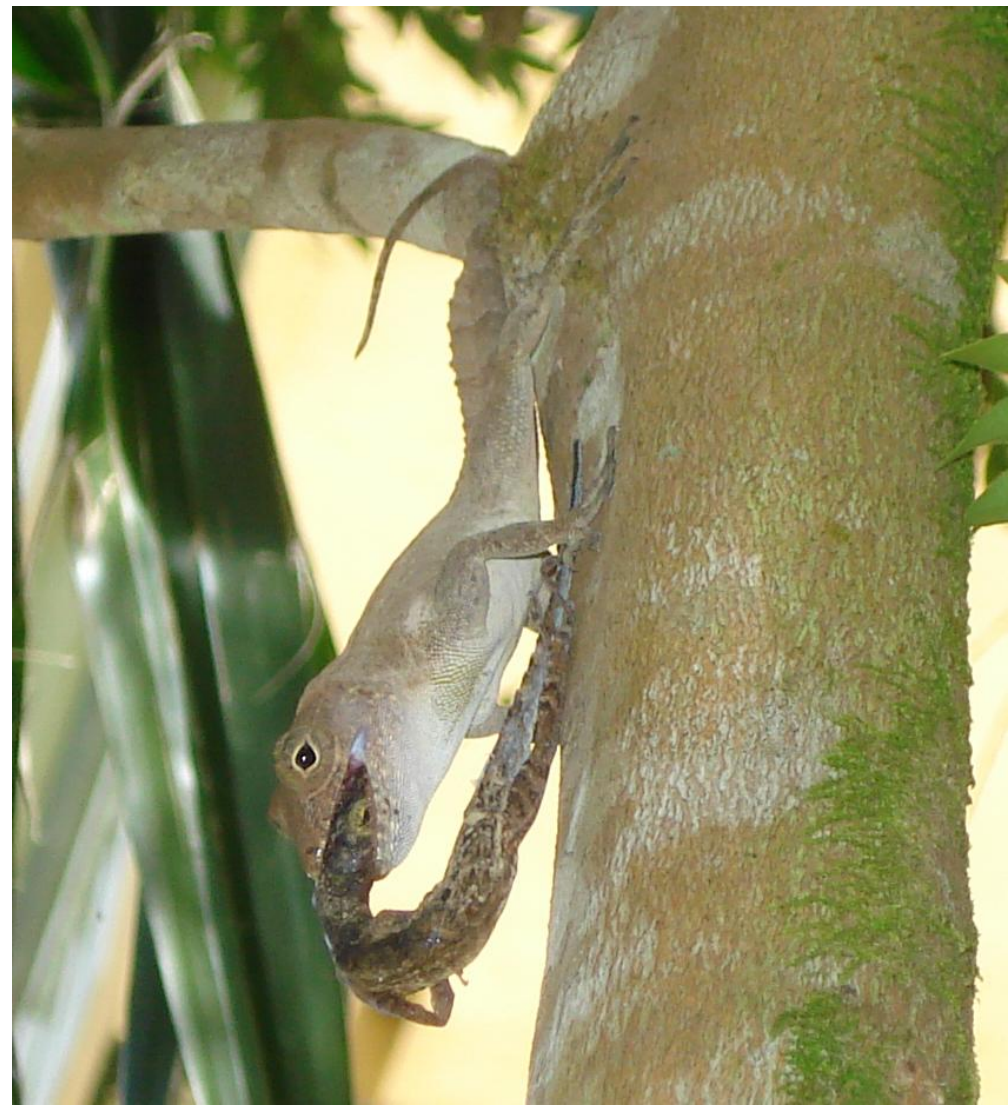

Figure 2. Male Anolis cristatellus ingesting an A. stratulus headfirst. Photo by N. RíosLópez.

This event took place at $1100 \mathrm{~h}$ in Carraízo, Trujillo Alto municipality, Puerto Rico $\left(18.342^{\circ} \mathrm{N}, 66.009^{\circ} \mathrm{W}\right)$. The observer heard a bone-crushing sound as A. cristatellus chewed the head of A. stratulus. At $1125 \mathrm{~h}$, A. cristatellus ingested A. stratulus to its forelimbs; at $1154 \mathrm{~h}$ had it ingested by midabdominal region; at $1210 \mathrm{~h} \mathrm{~A}$. cristatellus moved to a nearby Avocado tree, Persea americana Miller, 1768 (Laurales: Lauraceae), and had it ingested $A$. stratulus to its cloaca and the base of its tail. At $1214 \mathrm{~h}$, A. cristatellus had moved $3 \mathrm{~m}$ away from the avocado tree to an adjacent PVC fence as the observer reached closer to take additional pictures. Anolis cristatellus adopted a head-down posture on the fence and at $1241 \mathrm{~h}$, he regurgitated the A. stratulus, 
which then fell to the ground from approximately $1 \mathrm{~m}$ in height. At $1242 \mathrm{~h}$, the observer saw an adult female $A$. exsul that sprinted from the leaf litter, captured the A. stratulus, and ingested it instantly.

Lizard-Lizard opportunistic oophagy, saurophagy, and nest foraging. Different events revealed Puerto Rican Common Ground Lizards (Ameiva exsul) of varying body sizes (juveniles and adults), engaged into opportunistic feeding, nest foraging, and ingestion of the egg contents (yolk and developing embryos) of the Green Iguana (Squamata: Iguanidae: Iguana iguana Linnaeus, 1758). All these events took place in the facilities of Las Cabezas de San Juan Nature Reserve, in Las Croabas, Fajardo municipality, Puerto Rico (18.372 ${ }^{\circ} \mathrm{N}$, $65.630^{\circ} \mathrm{W}$ ), between 2008 and 2011 during the nesting season of the Green Iguana (from mid-February to early-June; López et al. 2011). On one of the occasions, CARG observed several individuals of the Ground Lizard feeding opportunistically on undeveloped eggs excavated from the iguana nest and that lay dispersed on the floor (the nest forager was not observed and could not be identified on this occasion). A Ground Lizard broke through the eggshell (Figure 3A) and slowly lapped the yolk in the eggs (Figure 3B). Stealing of eggs occurs among Ground Lizards: CARG observed several individuals stealing each other's catch of eggs. On another occasion, CARG was excavating a nesting site of the iguana in the plant nursery of the Reserve, as part of his Masters thesis project on the ecology and management of the Green Iguana (Rodríguez-Gómez, 2013), when several adult Ground Lizards snatched eggs from the clutch just excavated. Once away from the observer, the lizards would use its snout to peck at the eggs between 2 and 3 times before breaking through the shell: if the eggs were filled with yolk, the lizards would feed on it readily; if there is an embryo developed within the egg, a lizard would grab it with its mouth and ran away to the protective cover of the leaf litter in the adjacent forest to complete ingestion. Stealing of iguana embryos within the eggs also occurs among Ground Lizards: CARG observed several individuals of $A$. exsul engaged into a feeding frenzy over iguana embryos, sometimes dismembering embryos, and ingesting the portion of them that were taken from other lizard's catch. 

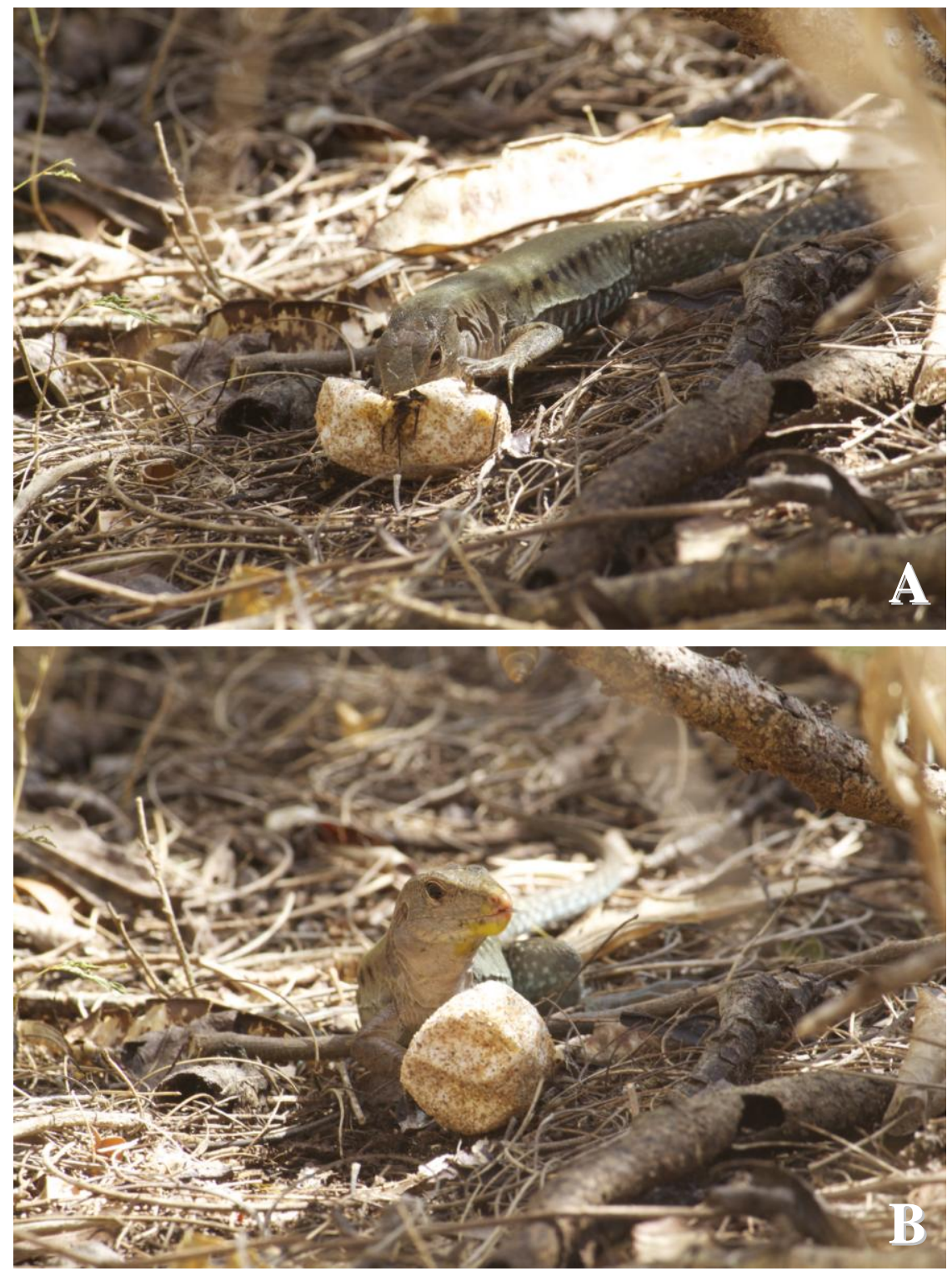

Figure 3. Adult Ameiva exsul feeding on egg yolk of Iguana iguana: the Ameiva dipping its snout into the egg for lapping the egg yolk (A) and showing its snout tinted yellow with egg yolk (B). Photos by C. A. Rodríguez-Gómez. 
Active nest foraging of the Green Iguana also occurs in the Ground Lizard. During April 2012, in Las Cabezas de San Juan Nature Reserve at 1200 h, in Las Croabas, Fajardo municipality, Puerto Rico $\left(18.380^{\circ} \mathrm{N}, 65.626^{\circ} \mathrm{W}\right), \mathrm{CARG}$ observed an adult Ameiva exsul entering through the opening of an iguana nest. Approximately 2 minutes later, the $A$. exsul exited from the nest with an iguana egg in its mouth, pecked at the egg several times until breaking its content open, and lapped its yolk.

Colubrid-Lizard saurophagy attempt. On January 1, 2007, NRL found an adult Puerto Rican Racer (Squamata: Colubridae: Borikenophis portoricensis Reinhardt and Lütken, 1862), with an estimated body length of $90 \mathrm{~cm}$, with an apparently freshly killed juvenile Iguana iguana (Figure 4). The iguana had an estimated snout-vent length (SVL) of $12.8 \mathrm{~cm}$ and a tail length of $28.9 \mathrm{~cm}$. This event took place in a parking lot of an apartment complex at $0902 \mathrm{~h}$, in Carraízo, Trujillo Alto municipality, Puerto Rico $\left(18.343^{\circ} \mathrm{N}, 66.009^{\circ} \mathrm{W}\right)$. The snake was disturbed by the approaching observer and moved downhill to a nearby forest, leaving the dead iguana in place.

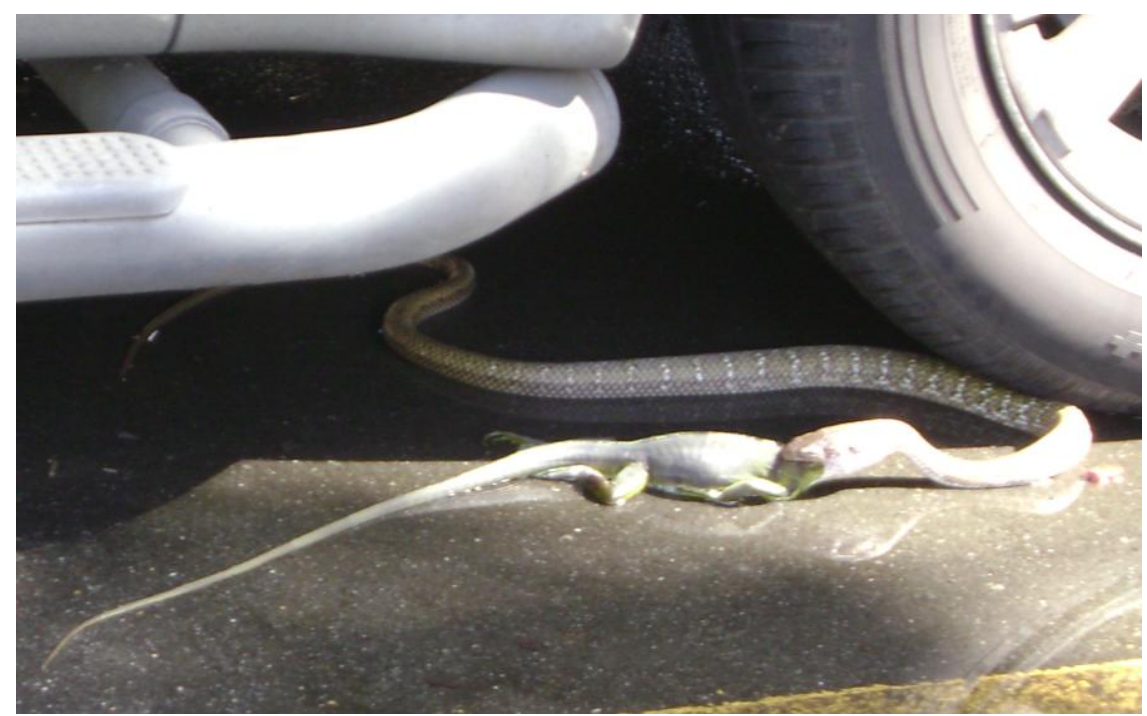

Figure 4. Adult Borikenophis portoricensis initiating ingestion of a juvenile Iguana iguana. Photo by N. Ríos-López.

Avian-Lizard saurophagy. Different events revealed an adult Great Egret (Ciconiiformes: Ardeidae: Ardea alba Linnaeus, 1758) capturing and ingesting an adult Ameiva exsul. The first event took place on September 4, 2009, adjacent to a parking area in an apartment complex at $1304 \mathrm{~h}$, in Carraízo, Trujillo Alto, Puerto Rico $\left(18.343^{\circ} \mathrm{N}, 66.007^{\circ} \mathrm{W}\right)$. NRL observed an egret that used its beak to pinch the lizard by its posterior left flank, ruptured its body 
exposing the lizard's mature ovules (or eggs), and clamped the lizard by its clavicle region behind the neck for ingestion (Figure 5A). A second event took place on December 28, 2012, at the edge of the road PR-175 at $1240 \mathrm{~h}$, in San Antonio, Caguas municipality, Puerto Rico $\left(18.297^{\circ} \mathrm{N}, 66.047^{\circ} \mathrm{W}\right)$. On this occasion, CJDV found an egret that had captured an adult $A$. exsul by its mid body; the lizard turned his head and engaged in a sustaining biting to the egret's beak (Figure 5B); the egret swallowed the lizard at $1242 \mathrm{~h}$ and flew to a nearby tree at $1247 \mathrm{~h}$. A third event took place on January 30, 2014, on a parking lot adjacent to the road PR-908 at $1328 \mathrm{~h}$, in Patagonia, Humacao municipality, Puerto Rico $\left(18.145^{\circ} \mathrm{N}, 65.835^{\circ} \mathrm{W}\right)$. On this occasion, NRL found an egret that had captured an adult $A$. exsul by the neck (not shown), without visible external damage to the lizard's body, and swallowed it whole by $1330 \mathrm{~h}$.

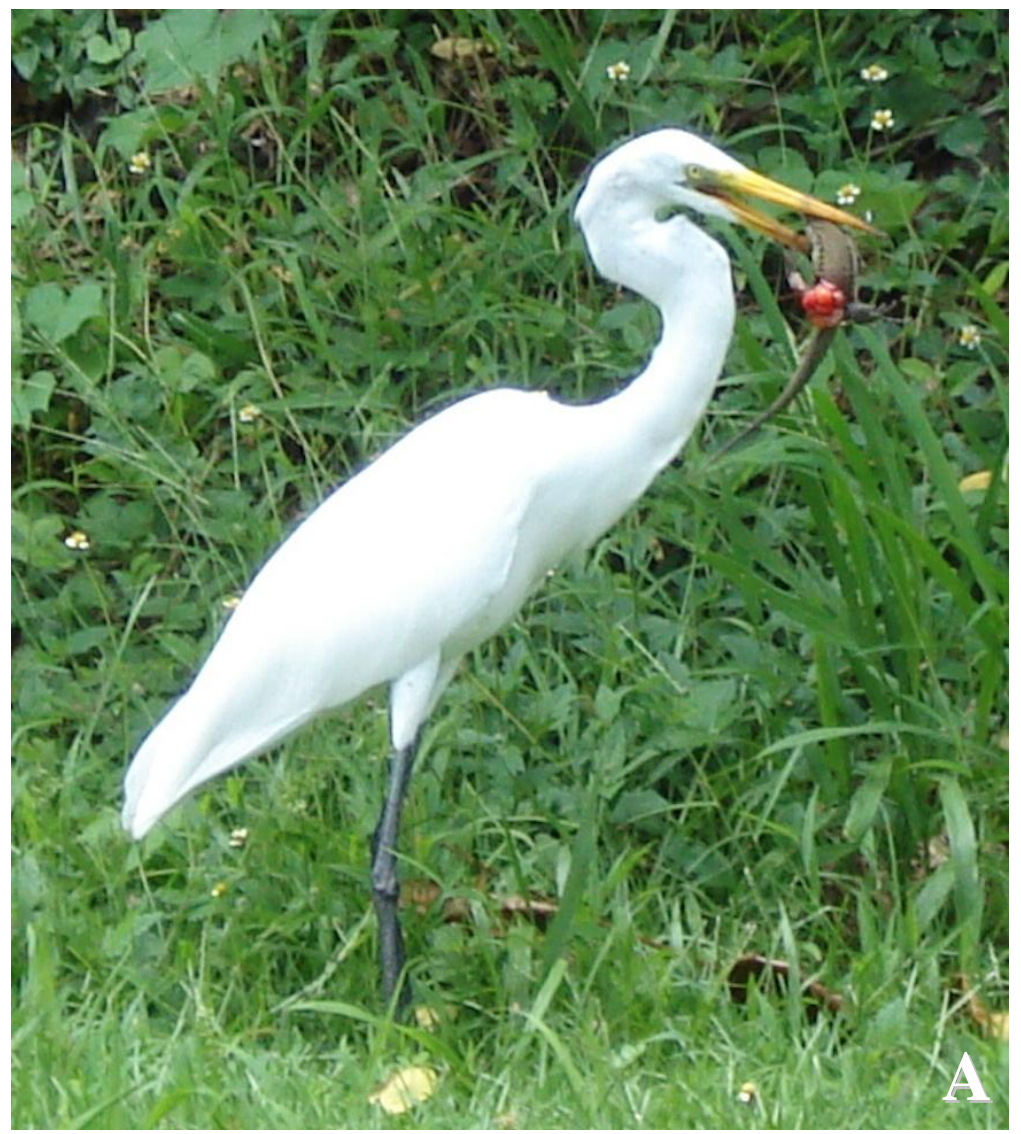

Figure 5A. Adult Ardea alba depredating an adult Ameiva exsul: eggs are visible protruding the posterior left flank of the female Ameiva. Photo in A by N. Ríos-López. 


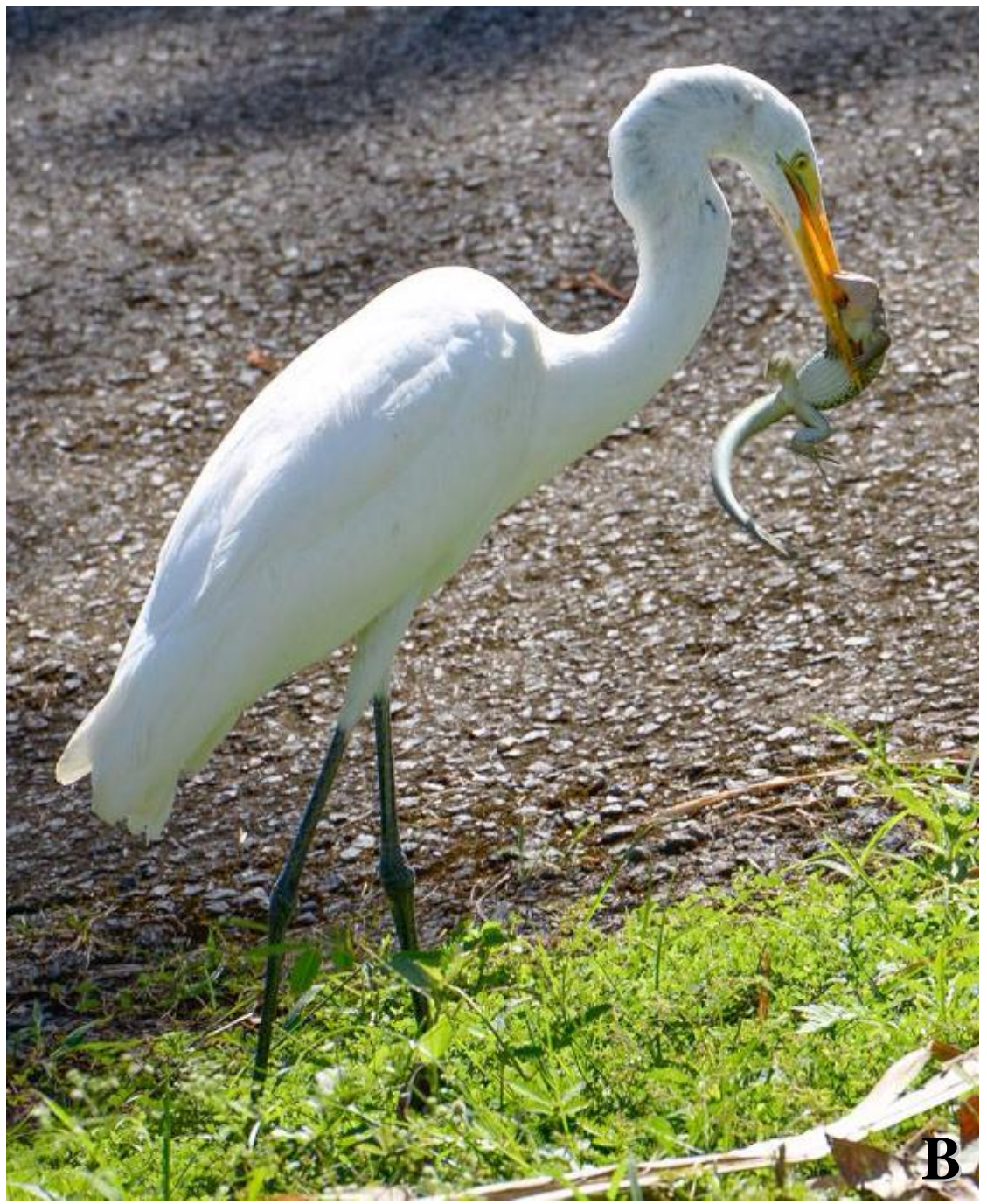

Figure 5B. Adult Ardea alba depredating an adult Ameiva exsul: Ameiva engaged into sustained biting for defense. Photo in B by C. J. Díaz.

On August 11 2013, NRL observed a Gray Kingbird (Passeriformes: Tyrannidae: Tyrannus dominicensis Gmelin, 1788) seizing, capturing, and preying a juvenile Ameiva exsul (estimated SVL $8 \mathrm{~cm}$, not shown). This event took place at $1100 \mathrm{~h}$, on a house's front yard in Bairoa, Caguas municipality, Puerto Rico $\left(18.261^{\circ} \mathrm{N}, 66.049^{\circ} \mathrm{W}\right)$. The bird was perching on a steel cable at a post, and dived down to the yard, missing the lizard on the first catch attempt. 
The bird returned to the cable, attempted to capture the lizard on additional two trials, and caught the lizard in the ground at its third attempt. The bird went up to the same cable, with the lizard still in its beak. The bird thrashed the lizardstill in its beak-against the cable as if it were to stunt it or kill it, swallowed the lizard whole, head first, and flew away of sight.

On May 5, 2007 RLJ observed an adult Pearly-Eyed Thrasher (Passeriformes: Mimidae: Margarops fuscatus Vieillot, 1808) predating a juvenile Iguana iguana. The event took place on May 5, 2007, in the main entrance of Las Cabezas de San Juan Nature Reserve at 0945 h, in Las Croabas, Fajardo municipality, Puerto Rico $\left(18.371^{\circ} \mathrm{N}, 65.632^{\circ} \mathrm{W}\right)$. At the time when the photograph was taken the Pearly-Eyed Thrasher had immobilized the Green Iguana between two branches, had ruptured its posterior right flank and used its beak to extract fragments of the iguana's internal organs (Figure 6).

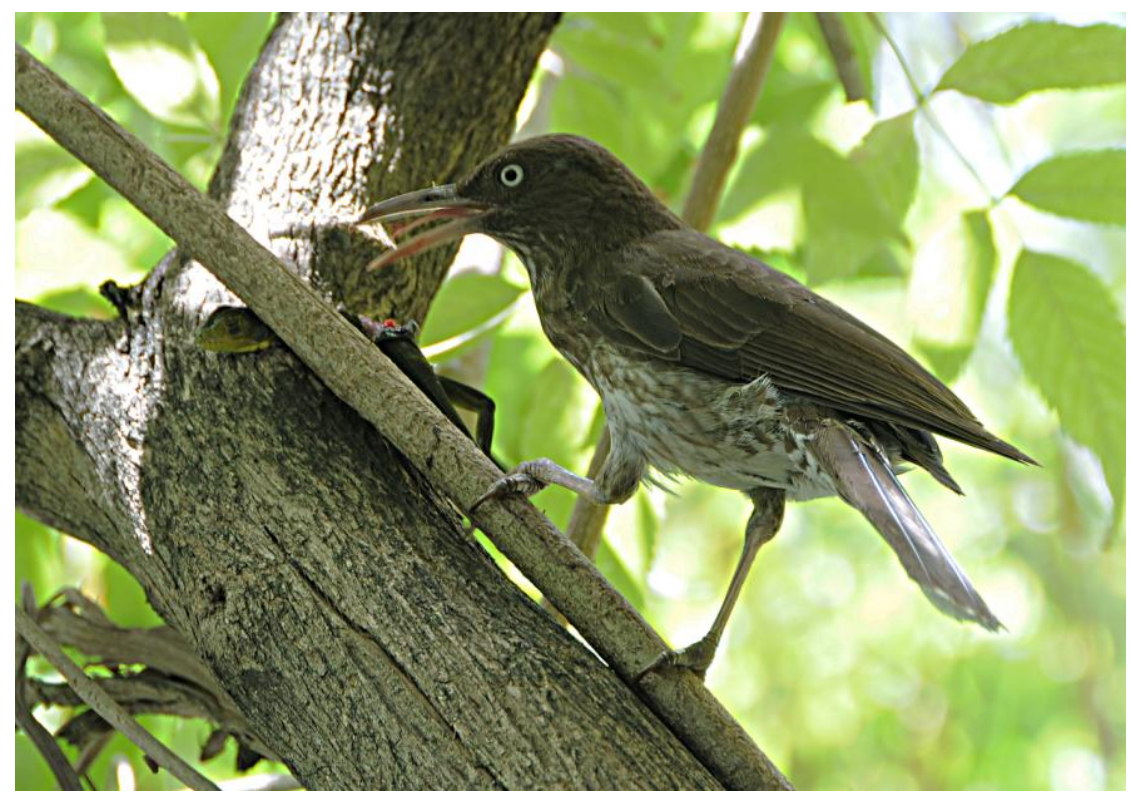

Figure 6. Margarops fuscatus depredating a juvenile I. iguana: the Pearly-Eyed Thrasher has ruptured the posterior right flank of the iguana. Photo by R. L. Joglar.

Different events revealed adult Laughing Gulls (Charadriiformes: Laridae: Leucophaeus atricilla Linnaeus, 1758) capturing and ingesting juvenile Iguana iguana. The first event took place on June 19, 2015, along the shore of Seven Seas Beach in Las Cabezas de San Juan Nature Reserve at 1258 h, in Las Croabas, Fajardo municipality, Puerto Rico $\left(18.373^{\circ} \mathrm{N}, 65.629^{\circ} \mathrm{W}\right)$. CARG observed a gull that was flying overhead and dived towards the sandy shore, where a juvenile iguana was sun basking (Figure 7A). 

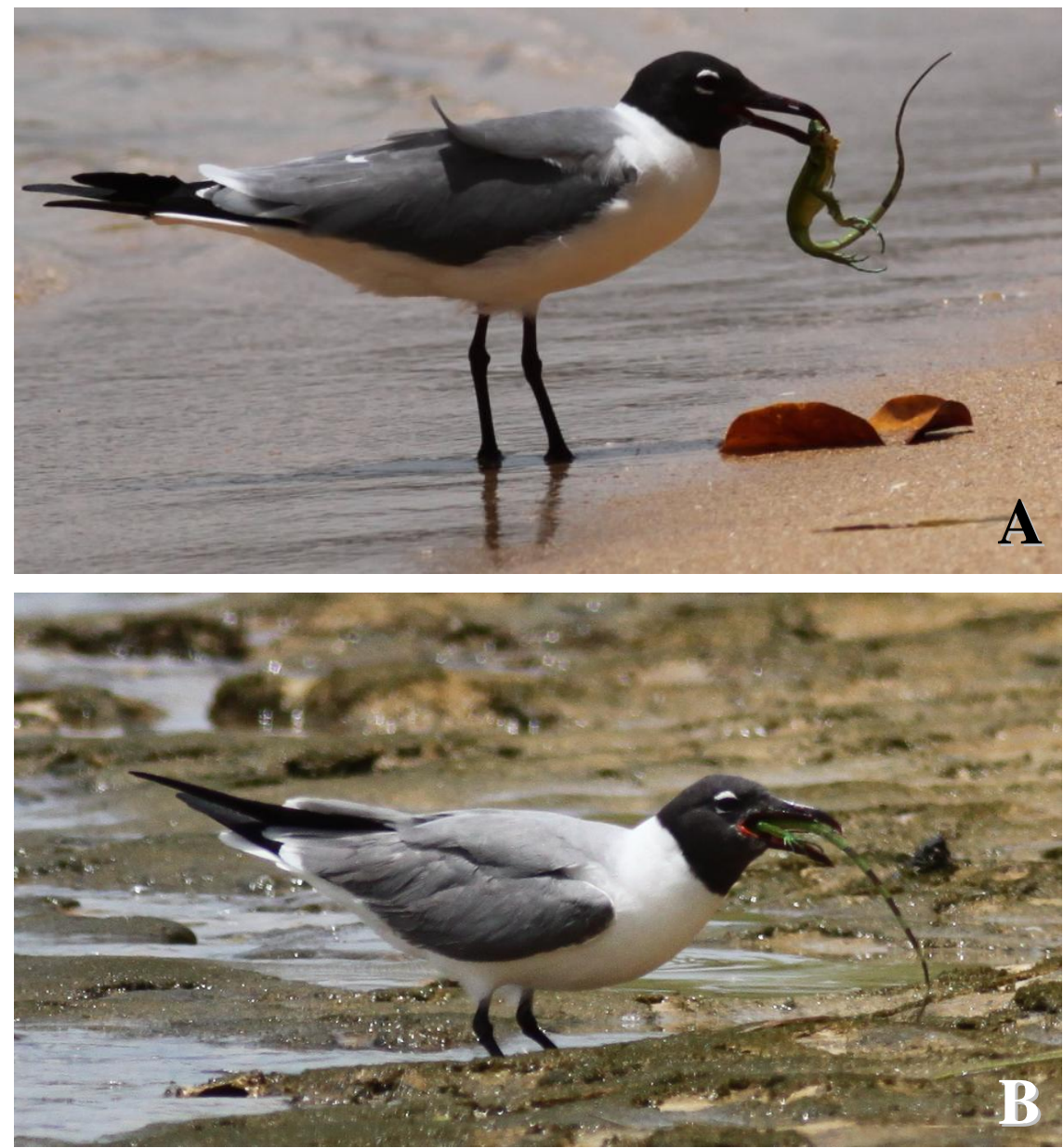

Figure 7. Adults Leucophaeus atricilla capturing and ingesting a juvenile Iguana iguana: the laughing gull had captured the iguana that was sun basking on the sandy beach moments ago and brought it into the shore for ingestion (A); in a different event, the laughing gull swallowing a juvenile iguana (B). Photos by C. A. Rodríguez-Gómez.

The iguana ran into the water, and once in the water, the gull following and capturing it. The iguana fell off from the gull's beak and into the water, but the gull captured it again - a sequence that repeated several times until the gull captured the iguana, moved to the shore with it in its beak, and ingested the iguana, head first, in four gulps. A second event took place on June 24, 2015, along the shore of Seven Seas Beach in Las Cabezas de San Juan Nature Reserve at $1330 \mathrm{~h}$, in Las Croabas, Fajardo municipality, Puerto Rico $\left(18.377^{\circ} \mathrm{N}, 65.626^{\circ} \mathrm{W}\right)$. CARG observed a Laughing Gull that captured and let 
loose a juvenile Green Iguana repeatedly - similarly as described above-to finally capturing and swallowing it whole, headfirst. On this occasion the tail of the iguana remained visible, protruding from the beak of the gull (Figure 7B). The gull then introduced its beak several times into the water and made several gulping movements until ingesting the iguana completely.

Two events revealed adult Pearly-Eyed Thrasher (Margarops fuscatus) predating on adult Mona Island Gecko (Squamata: Sphaerodactylidae: Sphaerodactylus monensis Meerwarth, 1901). Mona Island is a subtropical dry forest island of $55 \mathrm{~km}^{2}$ that lies approximately $74 \mathrm{~km}$ southwest of Mayaguiéz municipality, western Puerto Rico (Martinuzzi et al. 2008; Meléndez-Ackerman 2008). The first event took place on August 9, 2006, in Sardinera, Mona Island at 0811 h, Mayagüéz municipality, Puerto Rico $\left(18.087^{\circ} \mathrm{N}, 67.940^{\circ} \mathrm{W}\right)$. RLJ observed a Pearly-Eyed Thrasher that had captured an adult Mona Island Gecko from the leaf litter and was holding it with its beak by its pectoral girdle region (ingestion was not observed on this event; Figure 8A). The second event also occurred on August 9, 2006 in the same locality (approximately $20 \mathrm{~m}$ from the first event) at $0848 \mathrm{~h}$. RLJ observed an adult Pearly-Eyed Thrasher (which could well be the bird on the first event) that captured an adult gecko and it was getting ready to feed it to chicks in nest (Figure 8B). Approximately one minute later, the bird introduced the gecko into the open beak of one of the chicks.

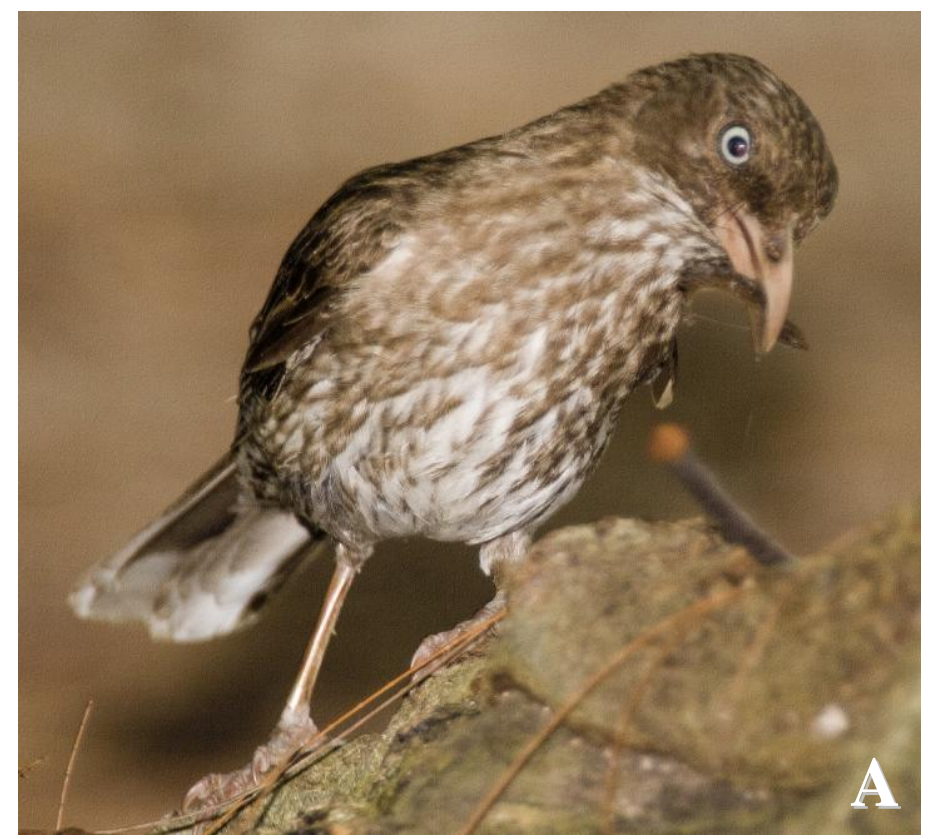

Figure 8A. Adult Margarops fuscatus capturing an adult Sphaerodactylus monensis: the Pearly-Eyed Thrasher with the Mona Island gecko in its beak. Photo by R. L. Joglar. 


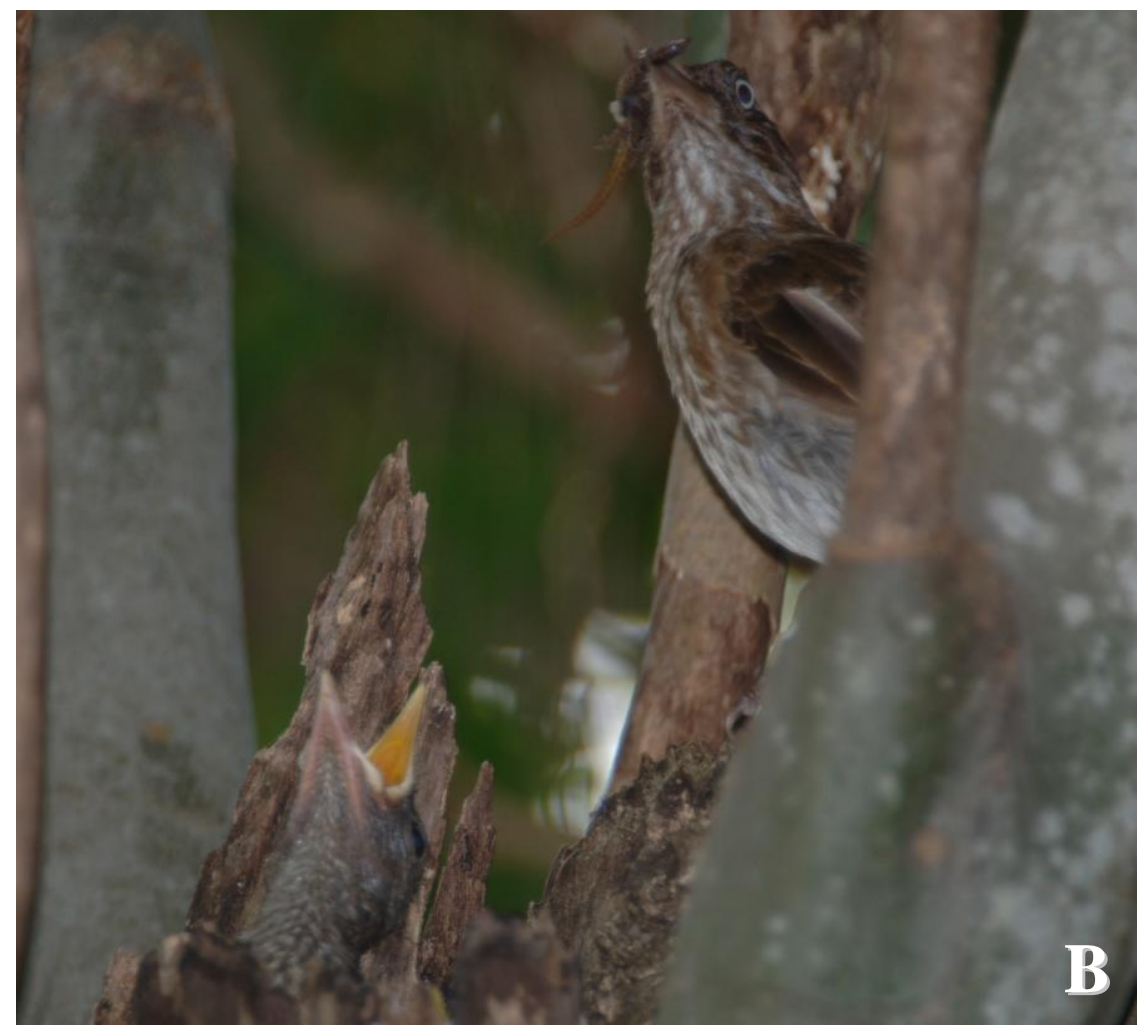

Figure 8B. Adult Margarops fuscatus about to feed a freshly caught adult gecko to a chick in its nest. Photo by R. L. Joglar.

On March 17, 2010, coauthor IR observed an adult Puerto Rican Tody (Coraciiformes: Todidae: Todus mexicanus Lesson, 1838) that had just captured and killed a juvenile Anolis cristatellus to feed its recently hatched chick in a nearby nest dug at approximately $60 \mathrm{~cm}$ height on a bare slope land adjacent to a trail. The Tody was found perching on a nearby branch of a shrub (Figure 9) in a cattle ranching farm located north of road PR-183, Sector Los Gómez, Valenciano Abajo, Juncos municipality, Puerto Rico $\left(18.183^{\circ} \mathrm{N}, 65.938^{\circ} \mathrm{W}\right)$. The ranch was characterized by low woody vegetation cover, is it adjacent to a semi-permanent creek, and has several artificial ponds and dirt roads. To our knowledge, this is the first record of lizard predation by the Puerto Rican Tody. 


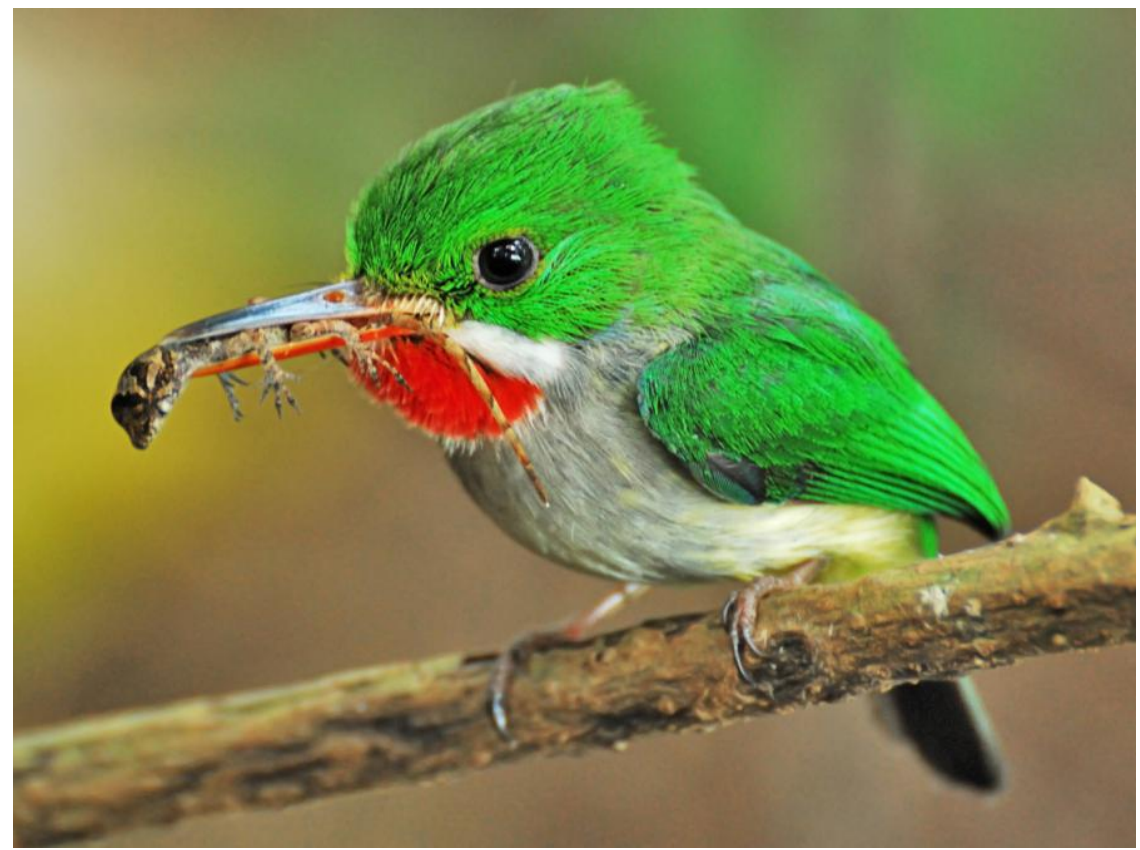

Figure 9. An adult Puerto Rican Tody, Todus mexicanus, with freshly caught juvenile Anolis cristatellus. Photo by I. Rivera.

Mammal-Lizard saurophagy. Different events revealed an adult Small Indian Mongoose (Carnivora: Herpestidae: Herpestes auropunctatus Hodgson, 1836) foraging nests, ingesting eggs, and capturing juvenile Iguana iguana. The first event took place during March 2009, on the western side of the lighthouse of Las Cabezas de San Juan Nature Reserve at 1400 h, in Las Croabas, Fajardo municipality, Puerto Rico $\left(18.382^{\circ} \mathrm{N}, 65.618^{\circ} \mathrm{W}\right)$. CARG observed an adult mongoose exiting the opening of an iguana nest while holding an egg in its mouth (not shown). The mongoose went to the adjacent vegetation for cover, presumably to ingest the egg content. A second event took place on June 25, 2015, along Seven Seas Beach of Las Cabezas de San Juan Nature Reserve at $1341 \mathrm{~h}$, in Las Croabas, Fajardo municipality, Puerto Rico $\left(18.382^{\circ} \mathrm{N}\right.$, $65.627^{\circ} \mathrm{W}$ ). CARG observed an adult mongoose that captured a juvenile iguana, which was foraging under the cover of shrubs along the beach line. The mongoose captured the juvenile by the right hind limb and carried it off in its mandibles to the denser adjacent vegetation inland, presumably for ingestion (Figure 10). 


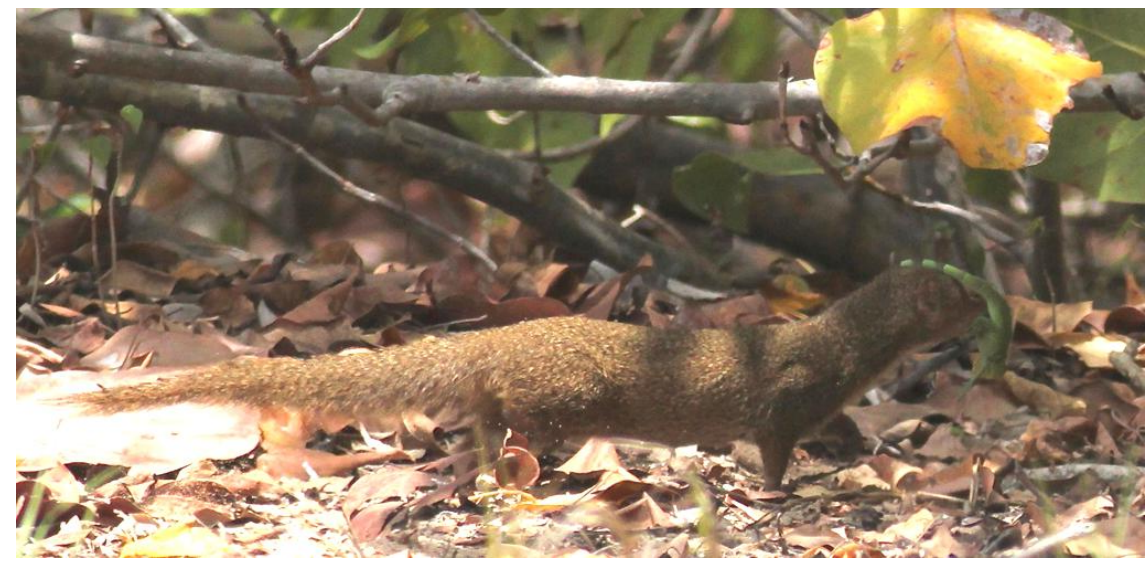

Figure 10. Adult Herpestes auropunctatus holding a recently caught young Iguana iguana in its mandibles, and retreating to the cover of the costal vegetation for ingestion. Photo by C. A. Rodríguez-Gómez.

One event revealed an adult domestic dog (Carnivora: Canidae: Canis lupus familiaris Linnaeus, 1758) predating a juvenile Iguana iguana (Figure 11). The event took place on August 9, 2014, in a residential area at $1031 \mathrm{~h}$, in Cupey, San Juan municipality, Puerto Rico $\left(18.366^{\circ} \mathrm{N}, 066.056^{\circ} \mathrm{W}\right)$. At the time when RLJ took the photograph, the dog had already captured the juvenile iguana by its mid body and swallowed the iguana whole afterwards.

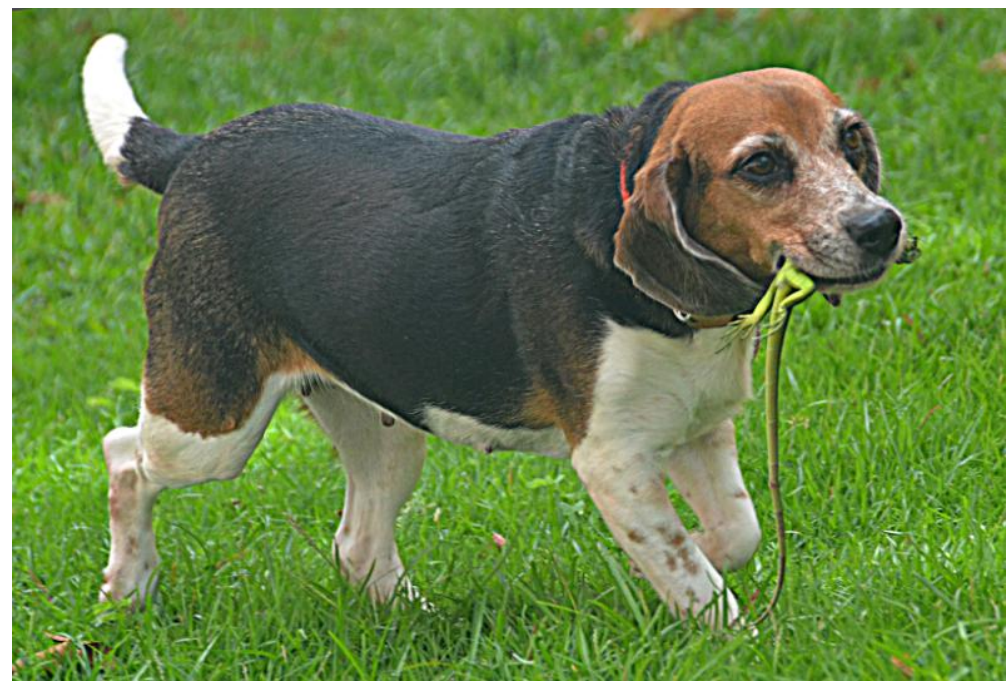

Figure 11. Adult Canis lupus familiaris holding in its mandibles a freshly caught juvenile Iguana iguana for ingestion. Photo by R. L. Joglar. 


\section{Discussion}

Lizard preys of Anolis cristatellus included the Grass-Bush Anole (A. krugi Peters; Sánchez-Muñoz 2008 in Henderson and Powell 2009, and in Losos 2009) and two unidentified Anolis lizards (Henderson and Powell 2009). Lizard predators of A. pulchellus and A. stratulus included the Puerto Rican Giant Anole (Squamata: Dactyloidae: A. cuvieri Merrem [preys on both species]), the Puerto Rican Green Anole or Evermann's anole (A. evermanni Stejneger, preys on A. stratulus), and the Yellow-Chinned Anole (A. gundlachi Peters, preys on A. stratulus) (Henderson and Powell 2009). Consequently, A. pulchellus and A. stratulus now increase the lizard-prey list for A. cristatellus. Likewise, predation of adult Ameiva exsul by the Great Egret and of juveniles by the Gray Kingbird (both non-raptor birds) also adds to the list of avian predators for the species. Previous reports on predation of $A$. exsul by non-raptor birds included only the Greater Antillean Grackle or 'Chango or Mozanbique' in Spanish (Passeriformes: Icteridae: Quiscalus niger Boddaert, 1783: Q. n. brachypterus Cassin, 1867), a species known to include in its diet Anolis lizards, Eleutherodactylus frogs, and the Caribbean White-Lipped Frog (Anura: Leptodactylidae: Leptodactylus albilabris Günther, 1859)(Wetmore 1916). Previous reports on predation of $A$. exsul by raptor birds included the American Kestrel (Falconiformes: Falconidae: Falco sparverius Linnaeus, 1758), and the Red-Tailed Hawk (Accipitriformes: Accipitridae: Buteo jamaicensis Gmelin, 1788) (Powell and Henderson 2008; Henderson and Powell 2009). Finally, prior reports of predation for the Mona Island Gecko, Sphaerodactylus monensis, included only the Mona Island Racer (Squamata: Colubridae: Borikenophis variegatus Schmidt, 1926) and feral cats (Carnivora: Felidae: Felis catus Linnaeus, 1758) (reviewed in Henderson and Powell 2009). Consequently, our report not only adds to the species' predator list, but suggests that the gecko could be an important prey item for birds raising their chicks in nests, and as such, an important component of the local food web on Mona Island.

The only prior report on Iguana iguana preyed by Borikenophis portoricensis came from the Water Island, U.S. Virgin Islands (Grant 1932h in Henderson and Powell 2009). Powell et al. (2005) listed mammalian predators of I. iguana, which included dogs, cats (on Saba and St. Marteen), and mongooses (on St. Marteen) on the Dutch Caribbean; Currat (1980) listed humans, cats, predatory birds, and eggs eaten by the Small Indian Mongoose and humans in the French Overseas Departments, Guadaloupe and Martinique; from the West Indies at whole, Powell and Henderson (2008) listed avian predators of I. iguana, which included raptors (Buteo jamaicensis and Falco sparverius) and "birds not usually considered predators of vertebrates" (emphasis provided) like the Pearly-Eyed Thrasher (Margarops fuscatus). This classification of the Pearly-Eyed Thrasher by Powell and Henderson (2008) may need revision as the species was known to feed on five species of lizards from 
Puerto Rico, a list now extended by the two species identified herein (one of them used for feeding chicks in nest). Throughout the West Indies, the list of prey lizards of the Pearly-Eyed Thrasher now increases to 14 species, five more than those listed for the Red-Tailed Hawk and just three species short from those listed for the American Kestrel (Table 1 in Powell and Henderson 2008).

Powell and Henderson (2005) mentioned seabirds (unidentified species) as predators of young iguanas in the Dutch Caribbean, but these authors were most likely referring to the Lesser Antillean Iguana (Squamata: Iguanidae: Iguana delicatissima Laurenti, 1768) in St. Eustatius instead of I. iguana. In their work, these authors mentioned also seabirds as predators of I. iguana, but bird species were not identified. Powell and Henderson (2008) did list the Laughing Gull, Leucophaeus atricilla, as predator of the Cuban Iguana (Squamata: Iguanidae; Cyclura nubila Gray, 1830: eggs and juveniles) and the Anguilla Black Ameiva (Squamata: Teiidae: Ameiva corax Censky and Paulson, 1992). Consequently, predation of I. iguana by the Laughing Gull from Puerto Rico represents a first record for both species through their geographic distribution in the Caribbean.

Surprisingly, our literature review resulted in not a single documented record of saurophagy in Iguana iguana from Puerto Rico, which makes our accounts most significant for three main reasons: (1) this species has been in the wild on Puerto Rico at least since the early 70s (presumably somewhat earlier; Rivero 1978; López-Torres et al. 2011, Joglar and Longo in prep.); (2) the species has expanded its geographic distribution within the island, from the driest costal areas at sea level in southwestern Puerto Rico to the mountain rain forest regions in protected areas like El Yunque National Forest in northeastern Puerto Rico (at least up to $660 \mathrm{~m}$ in elevation; N. Ríos-López, pers. obs.); and (3) adult individuals, particularly gravid females, are frequently subjected to road kill, presumably as females disperse for nesting and egg laying along urban areas elsewhere in Puerto Rico. In addition, while all cases of saurophagy of $I$. iguana herein described relate to juveniles, saurophagy of adult iguanas by domestic dogs has been observed in a wetland area in Sabana Seca, Toa Baja municipality, northern Puerto Rico. Here, dogs tend to hunt in packs along roadsides chasing and killing large iguanas by sustained biting and submission to death for consumption (N. Ríos-López, pers. obs.). As a result, it is evident that I. iguana has become highly abundant and probably, these accounts are more common in Puerto Rico (and elsewhere in the Caribbean) than it is suggested from evidence (or lack of it) in the literature.

The fact that a wide range of vertebrate predators, which include endemic, native, naturalized (sensu Lever 2003), and domestic animals in Puerto Rico readily recognized Iguana iguana as prey, suggests this naturalized lizard is a far more important component that increases diversity and resilience of local trophic webs. Future studies should examine the influence of the I. iguana on local trophic relationships, specifically on its potential for generating and maintaining indirect effects, presumably as this species may divert predator 
attention from large body-sized native species of ground nesting reptiles like the Puerto Rican Ground Lizard, the Puerto Rican Slider (Testudines: Emydidae: Trachemys stejnegeri Schmidt, 1928), and the Puerto Rican Racer, for example. That aside, our results now add to the assemblage complexity and related ecosystem processes brought in by naturalized species, through predator-prey interactions with native and endemic species in Puerto Rico. The large abundance and wide geographic distribution of many reptiles in Puerto Rico suggest that the evidence of saurophagy presented in this work represents a more common phenomenon than currently documented. Consequently, the few instances of saurophagy so far documented from Puerto Rico (and elsewhere in the Caribbean) may reflect a shortage of observations - and a shortage of the identification of species of predators and preys from anecdotal accounts (Powell and Henderson 2008) — that reach the scientific literature instead.

\section{Acknowledgments}

We wish to thank the kindness of J. Santiago-Blay for providing the photograph and detailed descriptions on saurophagy by Anolis cristatellus on A. pulchellus for this manuscript. We are indebted to A. R. Puente-Rolón and three anonymous reviewers who greatly improved this manuscript.

\section{Literature Cited}

Acevedo-Torres, M. A., N. Ríos-López, and M. Del C. Ruíz-Jaén. 2005. Epicrates inornatus (Puerto Rican Boa), Cannibalism. Herpetological Review 36(2):195.

Beard, K. H., A. K. Eschtruth, K. A. Vogt, D. J. Vogt, and F. N. Scatena. 2003. The effects of the frog Eleutherodactylus coqui on invertebrates and ecosystem processes at two scales in the Luquillo Experimental Forest, Puerto Rico. Journal of Tropical Ecology 19:607-617. http://dx.doi.org/10.1017/S0266467403006011

Currat, P. 1980. Reptiles des Antilles. Aperçu sur les reptiles Antillais de Guadeloupe et Martinique principalement. Document du CDDP. Association des Professeurs de Biologie et de Géologie de la Guadeloupe (APBG). Centre Départemental de Documentation de la Guadeloupe (CDDP), Pointe-à-Pitre, Guadeloupe. 119 pp.

Duellman, W. E. 1999. The West Indies and Middle America: contrasting origins and diversity. pp. 357-369. In, Caribbean Amphibians and Reptiles. Crother, B. I. (Editor). Academic Press, Hartcourt Brace and Company. San Diego, California, USA. 495 pp.

García-Moll, A. 1978. Abundance studies on the Anolis lizards and insect populations of altitudinally different tropical forest habitats. Center for Energy and Environment ResearchUniversity of Puerto Rico, Energy Research and Development Administration, U. S. Department of Energy. November 1978: 65 pp.

Henderson, R. W. and R. Powell. 2009. Natural History of West Indian Reptiles and Amphibians. University Press of Florida, USA. 528 pp.

Hillman, S. S., P. C. Withers, R. C. Drewes, and S. D. Hillyard. 2009. Ecological and Environmental Physiology of Amphibians. Oxford University Press. Oxford, England, UK. 469 pp.

Lever, C. 2003. Naturalized Reptiles and Amphibians of the World. Oxford University Press. New York, New York, USA. 344 pp.

López-Torres, A. L., H. J. Claudio-Hernández, C. A. Rodríguez-Gómez, A. V. Longo, and R. L. Joglar. 2011. Green iguanas (Iguana iguana) in Puerto Rico: is it time for management? Biological Invasions 14(1):35-45. http://dx.doi.org/10.1007/s10530-011-0057-0

Losos, J. B. 2009. Lizards in an Evolutionary Tree: Ecology and Adaptive Radiation of Anoles. University of California Press, Berkeley, California, USA. 507 pp.

Martinuzzi, S., W. A. Gould, O. M. Ramos-González, A. Martínez-Robles, P. Calle-Maldonado, N. Pérez-Buitrago, and J. J. Fumero-Cabán. 2008. Mapping tropical dry forest habitats integrating 
Landsat NDVI, IKONOS imagery, and topographic information in the Caribbean Island of Mona. Revista de Biología Tropical 56(2):625-639.

Meléndez-Ackerman, E. J., C. Cortés, J. Sustache, S. Aragón, M. Morales-Vargas, M. GarcíaBermúdez, and D. S. Fernández. 2008. Diet of feral goats in Mona Island Reserve, Puerto Rico. Caribbean Journal of Science 44(2):199-205.

Nicholls, K. E., B. I. Crother, C. Guyer, and J. M. Savage. 2012. It is time for a new classification of anoles (Squamata: Dactyloidae). Zootaxa 3477:1-108.

Odum, H. T., G. Drewry, and E. A. McMaham. 1970. Introduction to section E. pp. E3-E15. In, Odum, H. T., and R. F. Pigeon (Editors). A Tropical Rain Forest: A Study of Irradiation and Ecology at El Verde, Puerto Rico. U. S. Atomic Energy Commission. Oak Ridge, Tennessee, USA. $1674 \mathrm{pp}$.

Powell, R. and R. W. Henderson. 2008. Avian predators of West Indian Reptiles. Iguana 15(1):9-11.

Powell, R. and A. Watkins. 2014. First report of cannibalism in the Saba Anole (Anolis sabanus), with a review of cannibalism in West Indian Anoles. Reptiles \& Amphibian 21(4):136-137.

Powell, R., R. W. Henderson, and J. S. Parmerlee, Jr. 2005. The Reptiles and Amphibians of the Dutch Caribbean: St. Eustatius, Saba, and St. Marteen. The St. Eustatius National Parks Foundation (STENAPA), Gallows Bay, St. Eustatius, Netherlands Antilles. 192 pp.

Reagan, D. P. 1996a. The role of amphibians and reptiles in a West Indian rain forest food web. pp. 217-227. In, Powell, R. and R. W. Henderson (Editors). Contributions to West Indian Herpetology: A Tribute to Albert Schwartz. Contributions to Herpetology. Volume 12. Society for the Study of Amphibians and Reptiles. Ithaca, New York, USA. 457 pp.

Reagan, D. P. 1996b. Anoline lizards. pp. 321-345. In, Reagan, D. P. and R. W. Waide (Editors). The Food Web of a Tropical Rain Forest. University of Chicago Press. Chicago, Illinois, USA. $616 \mathrm{pp}$.

Reagan, D. P., G. R. Camilo, and R. B. Wade. 1996. The Community Food Web: Major Properties and Patterns of Organization. pp. 461-488, In Reagan, D. P. and R. W. Waide (Editors). The Food Web of a Tropical Rain Forest. University of Chicago Press. Chicago, Illinois, USA. 616 pp.

Rivero, J. A. 1978. Los Anfibios y Reptiles de Puerto Rico. Editorial Universitaria, Universidad de Puerto Rico. Río Piedras, San Juan, Puerto Rico, USA. 148 pp.

Rodda, G. H., G. Perry, R. J. Rondeau, and J. Lazell. 2001. The densest terrestrial vertebrate. Journal of Tropical Ecology 17:331-338. http://dx.doi.org/10.1017/S0266467401001225

Rodríguez-Gómez, C. A. 2013. A distribution model, nest temperatures, predators and results for a five-year management plan of Iguana iguana in Puerto Rico. Masters Thesis. University of Puerto Rico-Río Piedras. San Juan, Puerto Rico, USA. 167 pp.

Roughgarden, J. 1995. Anolis lizards of the Caribbean: ecology, evolution, and plate tectonics. Oxford University Press. New York, New York, USA. 226 pp.

Stewart, M. M. and L. L. Woolbright. 1996. Amphibians. pp. 273-320. In, D. P. Reagan and R. W. Waide (Editors). The Food Web of a Tropical Rain Forest. University of Chicago Press. Chicago, Illinois, USA. 616 pp.

Wetmore, A. 1916. Birds of Porto Rico. Bulletin of the U.S. Department of Agriculture, no. 326. 140 pp. http://dx.doi.org/10.5962/bhl.title.64703 